\title{
Autologous Peripheral Blood Stem Cells and $\gamma / \delta$ T Cells May Improve Immunity in Treating Secondary Bacteremic Infection in HIV Infected Patient
}

\author{
Ciro Gargiulo ${ }^{*}$, Van Hung Pham², Nguyen Thuy Hai', Kieu C. D. Nguyen ${ }^{3}$, Ngan Duong Kim¹, \\ Thinh Nguyen Van', An Luu Tuan', Kenji Abe', Veronica Flores', Melvin Shiffman' \\ ${ }^{1}$ Division of Internal Medicine, The Human Medicine International Clinic, Ho Chi Minh City, Vietnam \\ ${ }^{2}$ Molecular Diagnostics Department, Nam Khoa-Biotek Laboratory, Ho Chi Minh City, Vietnam \\ ${ }^{3}$ Division of Pathology, The Human Medicine International Clinic, Ho Chi Minh City, Vietnam \\ ${ }^{4}$ Department of Pathology, National Institute of Infectious Diseases, Tokyo, Japan \\ ${ }^{5}$ Sol Price School of Public Policy, University of Southern California, Los Angeles, CA, USA \\ ${ }^{6}$ Section of Surgery, Newport Specialty Hospital, Tustin, CA, USA \\ Email: ${ }^{*}$ dr.ciro@humanmedicine.com
}

Received 27 August 2015; accepted 21 October 2015; published 26 October 2015

Copyright (C) 2015 by authors and Scientific Research Publishing Inc.

This work is licensed under the Creative Commons Attribution International License (CC BY).

http://creativecommons.org/licenses/by/4.0/

(c) (i) Open Access

\begin{abstract}
Opportunistic bacteremia in adult HIV-infected patients is a normal co-infectious condition caused by Gram-negative bacilli. Respiratory infections, including cough, shortness of breath, and chest pain and skin infection with eruptions, pustules and itchiness, are common complaints in the setting of late HIV infection. The variety of infections ranges from mild, self-limited viral, bacteremia and fungal infections to severe, life-threatening demanding urgent care and hospitalization. Varicella pneumonia, for instance, is the most severe complication of chickenpox in HIV infected adults, potentially refractory, fulminant respiratory failure can ensue. Patients with impaired immune status and chronic lung disease are at an increased risk. In the United States as well as in Vietnam, bacterial/viral pneumonia and skin infection are the two most common HIV-associated conditions. While globally the incidence of opportunistic infection has decreased since the introduction of highly active antiretroviral therapy during the last 3 decades, HIV-associated diseases remain a significant source of mortality, thus any manifestation must be taken seriously. This study will present the most common HIV-related pulmonary and skin infections and provide an overview of the epidemiology, characteristic clinical and chest radiograph findings, diagnosis, treatment, and prevention globally as well in Vietnam. Though the extensive efforts of the Vietnamese Govern-
\end{abstract}

"Corresponding author.

How to cite this paper: Gargiulo, C., et al. (2015) Autologous Peripheral Blood Stem Cells and $\gamma / \delta$ T Cells May Improve Immunity in Treating Secondary Bacteremic Infection in HIV Infected Patient. Stem Cell Discovery, 5, 48-61.

http://dx.doi.org/10.4236/scd.2015.54006 
ment during last decade contributed to a valuable decrease, yet epidemic in Vietnam still remains high, ranking Vietnam $5^{\text {th }}$ in the South-East region. The second part of the study focuses on a unique and severe HIV case report of a 35-year-old man, with a rare form of pneumonia caused by Acitenobacter spp. concomitant with a prolonged and disseminating skin infection. The case has been treated with a combination of conventional anti-retroviral medication and autologous peripheral blood stem cells, the results showed that within 5 months there was an impressive amelioration of HIV viral activity together with a total recovery from pneumonia and skin infection.

\section{Keywords}

Human Peripheral Blood Stem Cells, $\gamma / \delta$ T Cells, NK Cells, Hematopoietic Stem Cells, CD4, CD8, HIV

\section{Introduction}

Bacteremia is a very common complication in HIV patients usually associated with a poor prognosis accountable for fast and serious morbidity and death, especially if associated with subtle pathological conditions [1]-[3]. A few specific causes in HIV affected patients may contribute to secondary bacterial infections, such as anomalies in humoral and cell-mediated immunity, neutropenia and a low CD4 T-cell count, phagocytic cell dysfunction, skin and mucous membrane deterioration, low hygiene, sharing of syringe among already infected drug users [4] [5]. The most common identified pathogens have been Staphylococcus aureus, Streptococcus pneumoniae, Salmonella spp. and Pneumocystis carinii [6]-[8]. The clinical importance of secondary bacterial manifestation in HIV infected patients has been acknowledged since the AIDS epidemic was systematically assessed as over $50 \%$ of patients could be affected by one or more bacterial infections during the progression of the disease [9]-[11]. In fact, the incidence of recurrent bacterial infections in HIV patient is an additional issue and is steadily increasing, mainly due to weakening of immune system, bacteria resistance and progressive invasiveness of modern medication [11]. Thus aggressive infections caused by Pseudomonas aeruginosa, for instance, tend to happen intermittently in patients with advanced AIDS and are often sign of poor prognosis, yet in general the mortality rate in such recurrent cases is well above 60\% [11] [12]. Of note, Bouza and colleagues were able to prove by molecular typing technique the existence of homologies amongst strains isolated in recurrent episodes of Pseudomonas bacteremia in HIV-infected patients [11]. In this study we report a rare case of HIV infected patient with secondary bacteremia caused by Acinetobacter spp., the site of infection were skin and lungs. As reported by Manfredi et al., Acinetobacter spp. is a rare opportunist pathogen that could be extremely dangerous for patients with HIV disease, especially in presence of low immunity, underlying sicknesses and hospitalization [13] [14]. Data from Manfredi and colleagues represents the largest study dealing with HIV-associated Acinetobacter spp. infections, which includes just 23 episodes of HIV-associated Acinetobacter spp., 9 cases of bacteraemia, 8 of pneumonia, 2 of urinary tract involvement, 1 of intravenous access device infection, 1 of meningitis and 2 with unspecified localization [14]. According to their report, it can be confirmed the existing relation between Acinetobacter spp. and morbidity among patients with HIV infection in presence of a low $\mathrm{CD}^{+}{ }^{+}$cell count, neutropenia and hospitalization are present [14]. Thus, Acinetobacter spp. potential pathogenic role in HIV disease should not be underestimated even without the occurrence of assumed risk factors, due to the strict contributing linking between these infections and immunodeficiency and other types of infectious complications [14].

\section{HIV Current Situation in Vietnam}

HIV epidemic in Vietnam during the last decade has been under a discrete control by the Vietnamese Government and its agencies [15]. Affected HIV individuals include three groups of subjects with high level of risk behaviors: drug users, men who have sex with men and female sex workers [15] [16]. Of course the risk behaviors in these populations are mutually inclusive and drug addiction increases the chance of HIV infection among the others [15] [16]. Recent report has confirmed a gradual increase of women infected, 32.5\% of new cases, a data that reflects a steady transmission of HIV by the partner who is engaging in high risk behaviors [15]. By the end of 2014 there has been an estimated 254,000 HIV infected individuals with an average of 14,000 new infections each year [15]. Without any doubt Vietnam as well as the majority of new developing countries such as Russia, 
Ukraine, the central Asian republics, Iran, China, Indonesia, Nepal, are paying the price of a fast and deep economic change that has had a deep impact on their social compartment [15]-[18]. In fact numberve has shown a dramatic increase of HIV infection trend during the first decade, between 1996 to 2005, soon after Vietnam open to the external world with its "Doi Moi" or "New Political Opening" strategy in 1994 (Figure 1, Figure 2) [15].

Curiously, as stated by an investigation conducted by United Nation Office on Drugs and Crime (UNODOC) this trend was closely related to the Afghanistan maximum pick of opium production which was during 20042006 (Figure 3) [19].

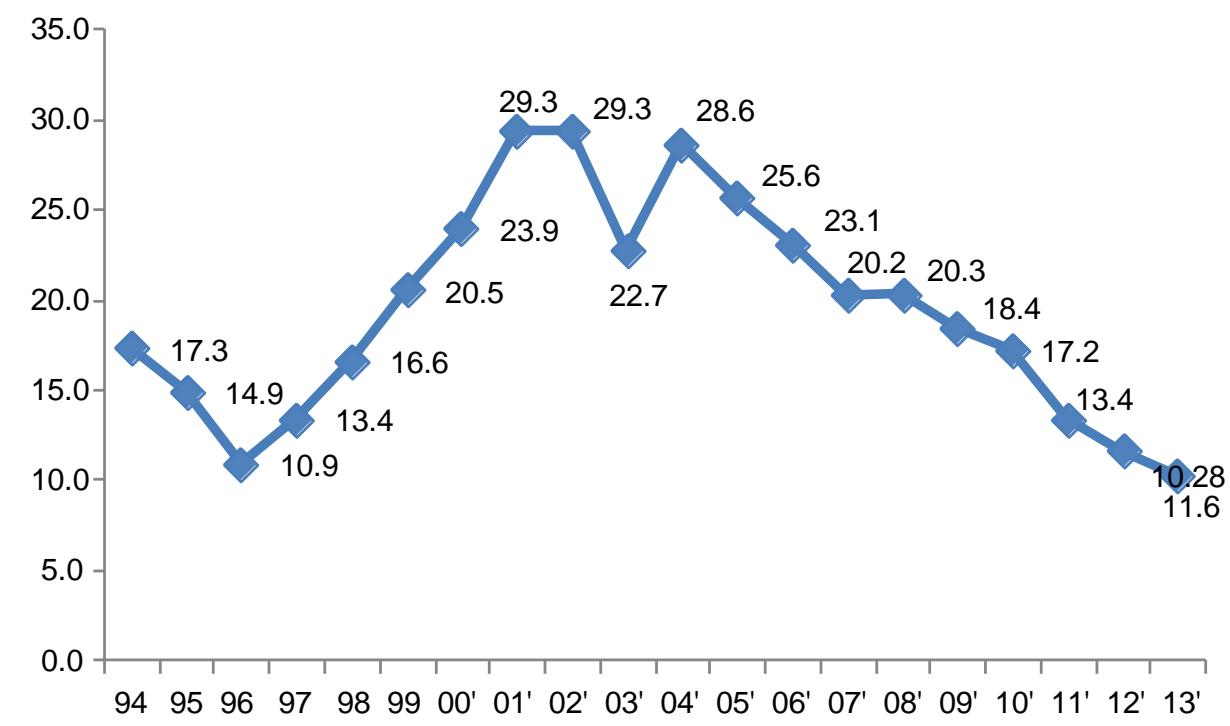

Figure 1. Trend of HIV among drug users in Vietnam during the decade 1994-2013. HIV prevalence among drug users during the period of 1994-2013 in Vietnam. The 2001-2005 it is a critical period which is commonly present in different developing countries as China, Indonesia, Russia, Ukraine, a period which is related to the most instability years in Afghanistan recent time political history [15].

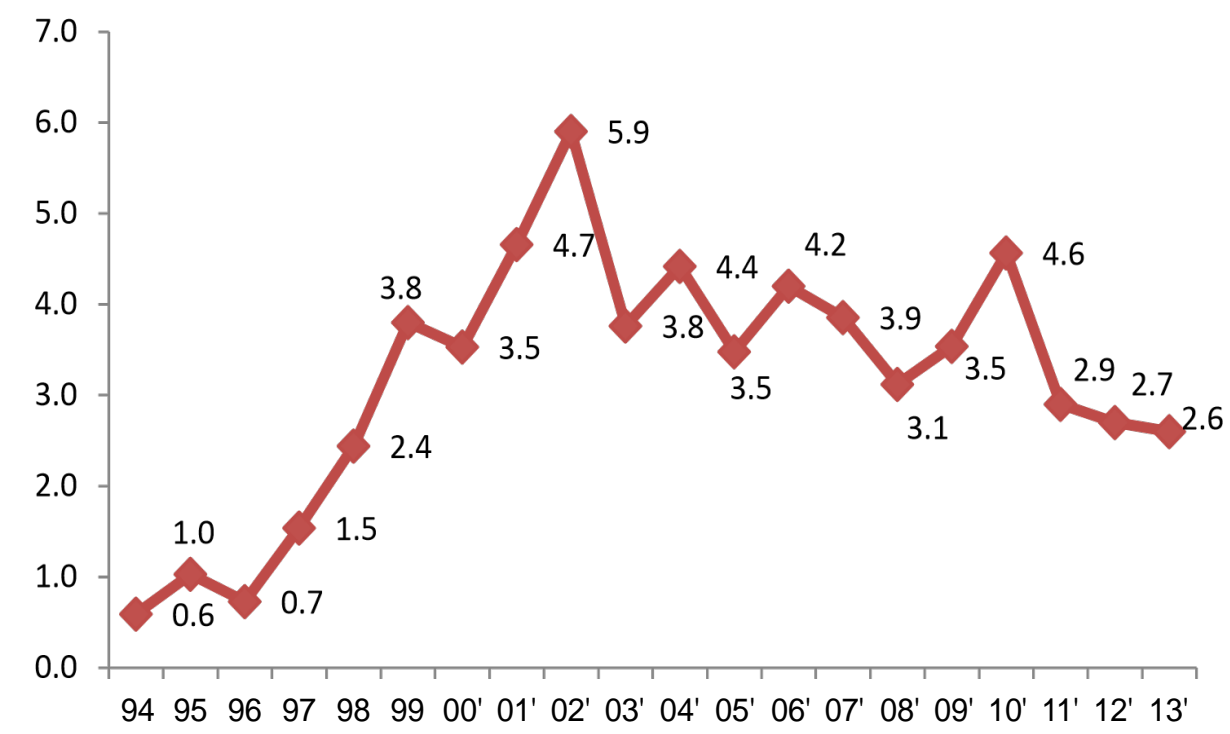

Figure 2. Trend of HIV among female sex workers during the decade 1994-2013. HIV prevalence among female sex workers 1994-2013 in Vietnam. Prostitution as for drug use increased during the five years 2001-2005 as consequence of "New Opening" policy and political instability of Afghanistan [15]. 


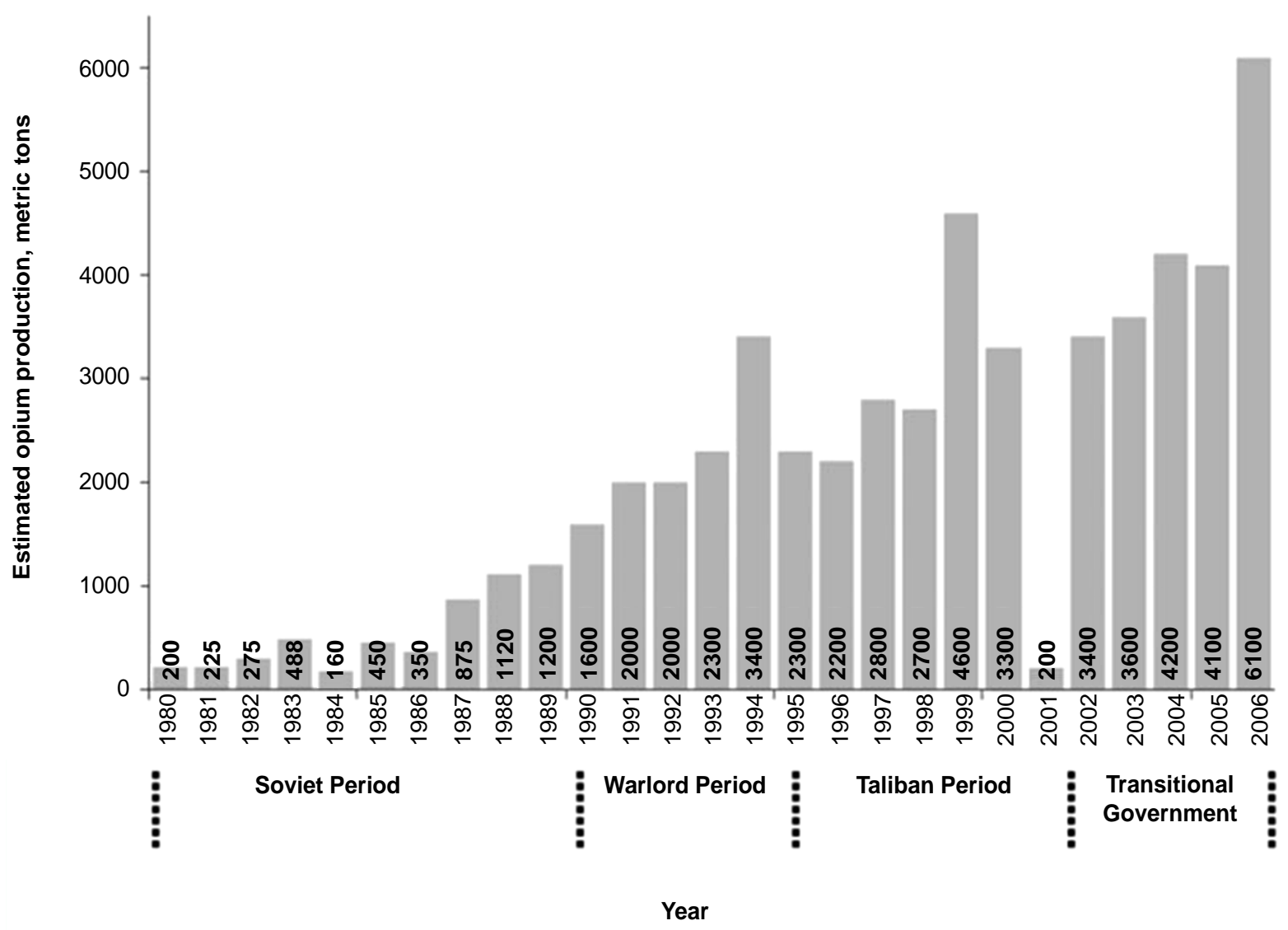

Figure 3. Trend of opium production in Afganistan during the period 1980-2006. Afghanistan opium production, in metric tons, from 1980 to 2006. UNODC World Drug Report for 2005 [19].

\section{Autologous Peripheral Blood Stem Cells Can Improve Immunity Response}

The main aim of this case report is to report the efficacy of PB-SCs in our HIV infected patient as supportive tool in increasing its own immunity against the aggressiveness of the virus. In a previous study, conducted by the author's team, it was established that human peripheral blood contain different sub-groups of pluripotent and multipotent stem cells that may represent a breakthrough in the field of regenerative medicine and in the treatment of degenerative diseases [20]. It is well established since over two decades the immune-modulatory capacity of stem cells, results of randomized trials has well confirmed that autologous HSC infusion following highdose chemotherapy supported a longer disease-free survival in hematologic malignancies as well as solid tumors, cases included non-Hodgkin's lymphoma in relapse, acute myelogenous leukemia and multiple myeloma [21]-[26]. While the increase number of neutrophils and platelets is a crucial target in hematologic recovery after intensive chemotherapy and stem cell transplantation, one should consider the recovery and well-functioning of immune system [21]. Usually an efficient recovery of lymphoid and immune effector cells is a very gradual process, and the rebuilding of regular humoral and cellular immunity may require a period that exceeds a year [21]. Immune reconstitution involves several components of the immune system which include an evident comeback of active B cells, a proliferation of thymic and extra-thymic T-cells, a reappearance of cytotoxic $\mathrm{T}$ cells and natural killer (NK) cells, and efficient antigen compartment crucial to rebuild the pre-transplantation immune condition [21]. The immediate time following the stem cell transplant $\mathrm{T} \mathrm{CD} 4^{+}$cells tend to decrease (due to a persistently low level of naive $\mathrm{CD}^{+} / \mathrm{CD}^{2} 5 \mathrm{RA}^{+} \mathrm{T}$ cells) whilst there is an increase of $\mathrm{T} \mathrm{CD8}{ }^{+} \mathrm{T}$ cells, $\mathrm{B}$ cells is also slowing down [27]. Therefore, restoration of immune function is not a consequential effect from a treatment whether it would be anti-cancer or anti-viral such as the case of HIV. Conversely, these treatments may have direct clinical implications due to the intensive use of cytotoxic drugs which may impair immunity surveillance and function, opening to a minimal residual possibility of tumorogenic cells or opportunistic pa- 
thogens. Damiani and colleagues have showed that this immune defection tends to involve antigen presentation mechanism [27]. Patients' antigen presenting cells (APC) such as dendric cells (DCs) are abnormal either numerically or functionally after transplant [27] [28]. Dendric cells are known to be the most powerful APC in inducing $\mathrm{T}$ cell activation, generated by pluripotent stem cells within marrow stroma, migrate to peripheral blood and then to tissues, where they detect, bind and process antigens activating $\mathrm{T}$ cells [29]. In this review, a combined strategy that could lead to enhancement of cellular immune function to take particular advantage of retro-antiviral treatment in HIV minimal secondary bacteremia will be a matter of debate.

\section{Peculiar Trait of Human Peripheral Blood Stem Cells}

The benefits of hPB-SCs have been weighed by several teams worldwide either in autologous or allogeneic procedure and this is a practice that has been performed since over 2 decades. There are positive advantages for using hPB-SCs, first these cells do not require ethic obligations which are needed for embryonic or umbilical stem cells; second, hPB-SCs are readily available and are less exposed to immunologic challenges, and third they can be harvested with very low risk to the donor [30]. In addition, there is no need for a prolonged culture in vitro and they are able to differentiate into diverse cell phenotypes as their counterpart from other sources [30]. Compared with conservative allogeneic bone marrow transplantation, hPB-SCs have fast hematopoietic re-formation with limited collateral effects or infectious complications and possible improvement of the graft-versus-leukemia (GVL) effect [31]. A recent study from our team assessed few peculiar traits of hPB-SCs. Results showed that it contains different sub-groups of pluripotent and multipotent stem cells [20]. Reverse transcription polymerase chain reaction (RT PCR) was used to identify the expression of multipotent markers Oct4, Sox2, OCN, Nestin, Nanog and DMP [20]. Flowcytometry analysis confirmed that both adherent and non-adherent mononucleated cells were positive for a panel of mutipotency and pluripotency markers such as CD44, CD73, CD90, CD133, CD 34, CD45, CD14, Nestin, SSEA3 and Tra1 [20]. It quantified the presence of 14 hormones and, it measured the ability of hPB-SCs to secrete high level pro-inflammatory cytokines TNF $\alpha$ and IL-6 and low level of pro-inflammatory cytokines IFNy and IL-2 [20].

\section{Distinctive Features of $\delta / \gamma$ T Cells}

$\delta / \gamma \mathrm{T}$ cells constitute a small population of T lymphocytes. Compared to $\alpha / \beta, \delta / \gamma \mathrm{T}$ cells show less TCR diversity, able to perform different and more specific activities. $\delta / \gamma$ T cells are particularly present within epithelial environment, intestine mucosa and react to stimuli from self-molecules that indicate potential danger or cellular stress showing a phenotype of both innate and adaptive immunity functioning as bridge between both arms of the immune system [32].. Most intriguing, $\delta / \gamma$ T cells have shown immune regulatory and antitumor proficiency [32]. Numerous studies marked out a strong proliferation of $\delta / \gamma \mathrm{T}$ cells in the peripheral blood of infected patients by pathogens and bacteria such as in tuberculosis, malaria, salmonellosis or in bacterial meningitis due to Haemophilus influenzae, Neisseria meningitidis, or Streptococcus pneumoniae [33]. This response may be due to $\delta / \gamma \mathrm{T}$ stimulation by one of two major sets of shared non-peptide compound such as alkylamines, non-phosphate compounds generally present in microorganisms and microbes [34]. $\delta / \gamma \mathrm{T}$ cells reaction takes place quite rapidly with secretion of chemokines and T helper 1 cytokines such as IFN- $\gamma$, and by enhancing NK, $\mathrm{NKT}$, and $\alpha / \beta$ T-cell response [35]. Another interesting feature of $\delta / \gamma \mathrm{T}$ cells is their role as macrophages/antigen-presenting cells capable of binding to peptide antigens and therefore stimulates both CD4 ${ }^{+}$and CD8 ${ }^{+}$ subsets of $\alpha / \beta$ T cells [36]. Depicted is a situation whereby $\delta / \gamma \mathrm{T}$ cells may play different fundamental roles as earlier immune responders to bacteria and antigens as well immune regulator providers which facilitate other lymphoid cell activity and response [36].

\section{Material and Method}

\subsection{Peripheral Blood Stem Cells Isolation}

Mononucleated cells were isolated from HIV infected patient's peripheral blood following the guidelines of Health Department Research Ethic Committee of Ho Chi Minh city-Vietnam (Helsinki Declaration). Mononucleated cells were isolated by density gradient centrifugation using Ficoll-Paque ${ }^{\text {TM }}$ PLUS (GE Healthcare, Uppsala, Sweden). A total of 15 blood samples (35 ml each) were carefully layered 1:2 on Ficoll-Paque and centrifuged at 
$300 \mathrm{~g}$ for $20 \mathrm{~min}$ at $20^{\circ} \mathrm{C}$. The mononucleated cell layer, $4 \times 10^{7}$, at the plasma-Ficoll interface, were aspired and was washed three times with phosphate buffered saline and cultured in $25 \mathrm{~T}$ flasks with free serum medium containing $2 \%(\mathrm{v} / \mathrm{v})$ penicillin-streptomycin at $37^{\circ} \mathrm{C}$ in a humidified atmosphere containing $5 \% \mathrm{CO}_{2}$ for a period of 15 days. Suspension and adherent mononucleated cells were cultured in free serum medium (FSM-Life, Technology-CTS ${ }^{\mathrm{TM}}$-StemPro ${ }^{\circledR}$, Canada). For both suspension and adherent mononucleated cells, the trypan blue exclusion assay was used to observe the proliferation of the cells. At day $14^{\text {th }}$ small sample were aspired to be analyzed for bacteria, fungal and viral contamination. At day $15^{\text {th }}$ suspension and adherent cells were collected and injected to patient (Figure 4).

\subsection{Peripheral Blood T Cells $\delta / \gamma$ Isolation}

T cells $\delta / \gamma$, total $6.300 .000 / \mathrm{ml}( \pm 3 \%)$, were isolated from patient’s peripheral blood, from 6 units of $35 \mathrm{ml}$ each. The procedure was performed by using EasySep ${ }^{\mathrm{TM}}$ Human Gamma/Delta T Cell Isolation Kit by negative selection. Unwanted cells were targeted for removal with Tetrameric Antibody Complexes recognizing non- $\delta / \gamma \mathrm{T}$ cells and dextran-coated magnetic particles. The labeled cells are separated using the EasySep ${ }^{\mathrm{TM}}$ magnet without the use of columns. The desired cells were poured off into a new tube and mixed with $1 \mathrm{ml}$ of plasma obtained by centrifugation from patient's blood.

\subsection{Flowcytometry}

The patient was screened for disease that potentially cause lymphocyte homeostasis perturbation,CD45, CD3, CD4, CD8, CD19, CD56, CD16. Counts were performed by use of a MultiSET (BD FACScaliber) flow cytometer equipped with automated acquisition and analysis software.

\subsection{Cell Count by Hemocytometer}

The formula is $c=n / v$ where $c$ is cell concentration (cells $/ \mathrm{ml}$ ). It has been used Neubauer slides, the depth of chamber is $0.1 \mathrm{~mm}$ and it has been used the central chamber $\left(1 \mathrm{~mm}^{2}\right)$, and $v$ is $1 \times 10^{-4}$, therefore the final formula is $c=n \times 10^{-4}$.

\section{Case Description}

In middle November 2014, a 35-year-old man was admitted to our facilities due to HIV collateral manifestation. Clinical history showed that in August 2014, the patient was admitted to local general hospital facility in Ho Chi Minh City, VN, with a 7, rhinitis, muscular stiffness, fatigue and lower limb disseminated skin rashes with pruritus. He is from a wealthy family, married with two children, citing normal heterosexual life with no use of illicit drugs and alcohol. CBC results were within normal limits, abdominal ultrasound revealed Gall Bladder polyp
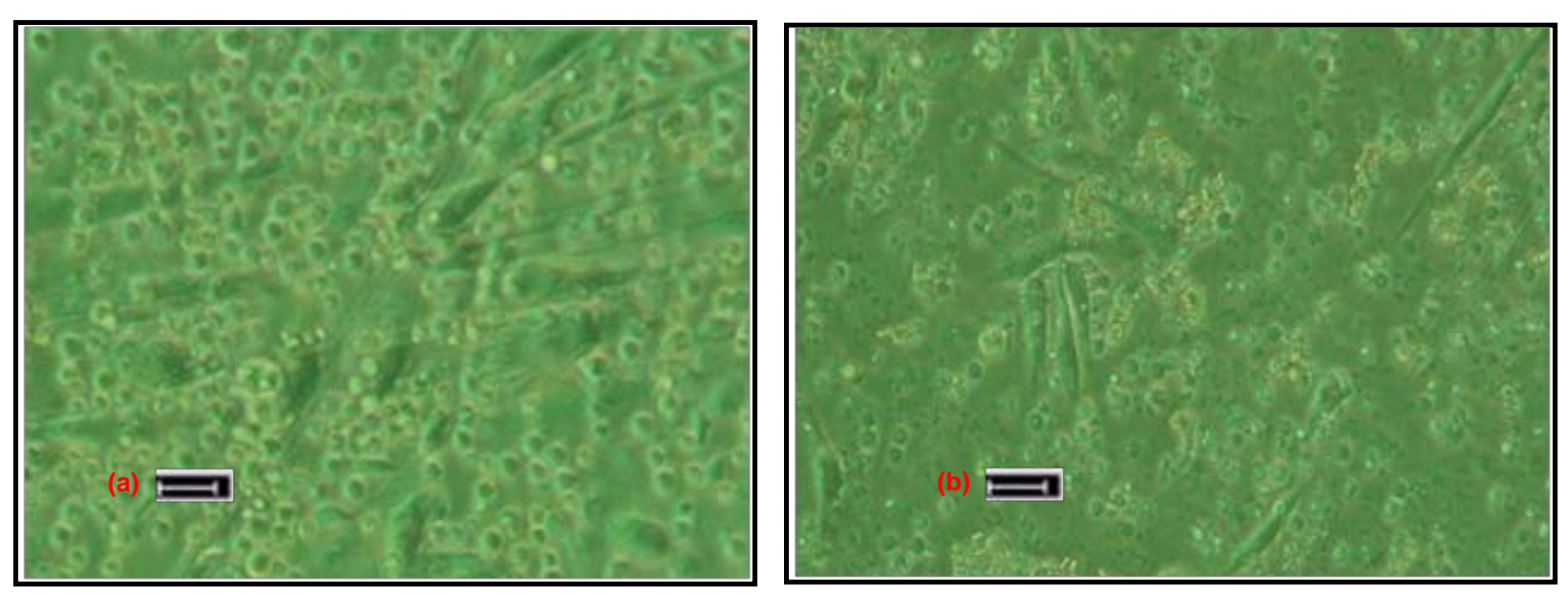

Figure 4. A and B show Peripheral Blood SCs from patient at day 7, MSCs, HSCs and ESCs 100x magnification. Peripheral Blood SCs from patient at day 7, MSCs with their fibroblast elongate shape are recognizable under spherical round shape HSCs and ESCs 100x magnification. Scale bar $=50 \mu \mathrm{m}$. 
(2 mm). The patient was released with medication and was booked an appointment for October. In October 2014, the patient's condition was considered stable, however physical and mental fatigue revealed to be worse than before. CBC showed normal count, low HDL $0.72 \mathrm{mmol} / \mathrm{L}$ (normal range $>9 \mathrm{mmol} / \mathrm{L}$ ), low Calcium 1.39 mmol/L (normal range 2.15 - $2.6 \mathrm{mmol} / \mathrm{L}$ ), high CRP $5.44 \mathrm{mg} / \mathrm{L}$ (normal range < $1 \mathrm{mg} / \mathrm{L}$ ), high IL-6 9.03 ug/ml (normal range < 1 - $2 \mathrm{ug} / \mathrm{ml}$ ), low Leptin $1.58 \mathrm{ng} / \mathrm{ml}$ (normal range $3.6-11.1 \mathrm{ng} / \mathrm{ml}$ ) low Testosterone $340 \mathrm{ng} / \mathrm{dl}$ (normal range 240 - $1200 \mathrm{ng} / \mathrm{dl}$ ), high FSH $8.58 \mathrm{mIU} / \mathrm{ml}$ (normal range 1.5 - $12.4 \mathrm{mIU} / \mathrm{ml}$ ), LH mildly high 4.35 $\mathrm{mIU} / \mathrm{ml}$ (normal range $0.7-7.9 \mathrm{mIU} / \mathrm{ml}$ ). The doctor decided to start a treatment with testosterone with weekly follow up. In November 2014, the patient felt his condition was getting worse. Major complaints were gastric pain, sore throat, dry cough with morning phlegm; physical examination revealed asymptomatic neck and throat lymph adenopathy. Another blood analysis was requested, results showed low level of WBCs 2.70 Ku/L (normal range 4 - $11 \mathrm{Ku} / \mathrm{L}$ ), Neutropenia $1.47 \mathrm{Ku} / \mathrm{L}$ (normal range 2.0 - $7.7 \mathrm{Ku} / \mathrm{L}$ ), Lymphopenia $0.85 \mathrm{Ku} / \mathrm{L}$ (normal range 1.2 - $4 \mathrm{Ku} / \mathrm{L}$ ), very low HDL $0.58 \mathrm{mmol} / \mathrm{L}$ (normal range $>9 \mathrm{mmol} / \mathrm{L}$ )), low total Cholesterol (2.88 $\mathrm{mmol} / \mathrm{L}$ ). Results from gastro-endoscopy revealed an inflammation of stomach wall while reports from throat culture revealed Candida infection. By early December the patient was hospitalized due to severe intestinal infection with prolonged watery diarrhea, HIV test performed by Pasteur institute of Ho Chi Minh City confirming positivity for the virus, T-CD4 (25.00 $\mathrm{mm}^{3}$, normal range $\left.576-1254 \mathrm{~mm}^{3}\right)$; RT-PCR confirmed high activity of virus; CBC showed marked eosinopenia and lymphopenia. His weight from $64 \mathrm{~kg}$ dropped down to $57 \mathrm{~kg}$. He was immediately prescribed retro anti-viral medication following Vietnamese Ministry of Health guide-line. By the end of December and early January 2015 the patient visited our facility complaining of further deterioration of his health condition including dry cough, mild breathlessness was more persistent during last few days, and diarrhea still was an on-off prominent manifestation. Examination revealed a mild febrile, tachypnea with a diffuse polymorphic skin rash with papules, vesicles and pustules; some showing evidence of crusting and spreading to upper part of the trunk (Figure 1). Auscultation of the chest revealed diffuse upper-right lateral crepitations. Blood cultures were positive for Acinetobacter spp. Radiograph of the chest revealed modest nodular and confluent infiltrates and right lung consolidation (data not shown the patient lost the radiograph). Diagnose was HIV pneumonia caused by Acinetobacter spp, a quite rare opportunistic infection. Levofloxacin 1000 mg per day, for 15 days, was commenced as initial empiric therapy supported by an anti-diarrhea medication. The $20^{\text {th }}$ December was decided together with patient and his family for the first cycle of stem cell therapy, autologous peripheral blood stem cells (aPB-SCs). Middle of January 2015 the patient was sent to Pasteur Institute for a second Test, TCD4 raised up to $217 \mathrm{~mm}^{3}$, CBC were within normal range, virus activity screened by RT-PCR showed that virus activity could not be detected as it was under 100 copies/mL, bacteria culture was negative. By the beginning of February, patient's clinical symptoms were mildly improving, patient was gaining back appetite, weight and vitality; yet, skin itching and rashes remained noticeable, dry cough especially morning and evening and rhinitis were still an issue. Therefore, a chest x ray was ordered, results evidenced a complete upper right lung lobe infiltration with few central bilateral calcification/fibrosis and heart enlargement. By 13 of February 2015 it was decided, with the consensus of the patient and family, to start a second cycle of stem cells which included the combination of T cells $\gamma / \delta$ and PB-SCs. A second x ray was performed a month later, beginning of March, the image showed a clear amelioration of infiltration which was reduced by $20 \%$ with less fibrosis and, noticeably reduced heart enlargement. The patient was monitored closely weekly and, in April 2015 was performed another immunology test at Pasteur Institute, TCD4 were $205 \mathrm{~mm}^{3}$. By the end of May patient's condition was definitively improved, cough, skin rashes and rhinitis were fully gone. CBC appeared normal, IgA, IgG and IgM were within normal range, Il2-6 and IFN $\gamma$ were normal, exception was IgE at limit high (132.7, normal range $<130 \mathrm{UI} / \mathrm{ml}$ ) and low level of Testosterone (2.2, normal range $2.4-12 \mathrm{mg} / \mathrm{dl}$ ); $\mathrm{x}$ ray showed a complete remission of infiltration and fibrosis. At present the patient is still under our weekly observation and cure.

\section{Treatment Procedure and Strategy}

The treatment procedure was conducted for a period of 4 and half months. Collected PB-SCs and $\delta / \gamma$ T cells were partly injected via IV and partly on specific body location such as tonsils injecting through base of the throat, in the proximity of axillary lymph nodes in the axillary plexus, sub-cutaneous on sternum at the level of nipples and through cervical vertebrae between C6-7 directly into spinal canal. The cell therapy was supported 
by administrating the patient a list of medication which included anti-oxidants, growth factors (human placenta extract), iron, amino acids and nootropic medicines. Cells were enriched with $0.5 \mathrm{ml}$ of human placenta at moment of injection. The main intent was to rebuild a balanced and supportive physiological micro-environment for stem cells improving meanwhile the endogenous auto-immune defenses of the patient.

\section{Discussion}

Although the regeneration of the CD4 T-cell pool may take some time due to the absence of normal thymic function, cellular immunity recuperates effective activity only within the first 3 months after transplantation [21]. Human PB-SCs have shown in recent years to have positive impact on immune reconstruction in comparison to BM, although the advantages of hPB-SCs are still to be clarified and better understood. In this specific case, stem cell immunotherapy could be defined as the effort in vivo with the specific intent to improve and regenerate immune responses against pathogens and bacteremia secondary to HIV infection. As proposed here, these attempts can be classified into two main clinical approaches: induction of non-specific cytotoxicity and the activation of specific cellular immunity. The non-specific method may include the administration of hormones, growth factors or anti-oxidants from the previous collection of peripheral blood for the isolation of stem cells in combination with use of retro-viral therapy (Figures 5-7). The activation of cellular immunity can be achieved by the combination of transplantation of both hPB-SCs and $\delta / \gamma \mathrm{T}$ cells approach in concomitance that may shorten the time of immunity recovery. Overall, autologous hPB-SCs and $\delta / \gamma \mathrm{T}$ cells transplantation in this severe case report had demonstrated remarkable clinical, laboratory, and morphological improvement. Medical evaluation has seen visible amelioration of patient's clinical condition as secondary bacteremia infection caused by Acinetobacter spp. was eradicated. By the end of fifth month lungs, sinus, diarrhea and skin infection have vanished (Figures 8-10), and patient has gained weight, more physical robustness and more mental energy; laboratory

\begin{tabular}{lllll}
\hline Human Placenta Extract & Placenta Lucchini & Switzerland & $0.5 \mathrm{ml}$ & 5 times \\
L-Ornithine-L-Aspartate $500 \mathrm{mg} / 5 \mathrm{ml}$ & Inbionethepatin & Korea & $5 \mathrm{ml}$ & 5 times \\
Recombinant Human Erythropoietin & Hemax $\mathbf{4 0 0 0 I U}$ & Argentina & $1 \mathrm{ml}$ & 5 times \\
Testosterone & Sustanon $\mathbf{2 5 0}$ & Netherlands & $1 \mathrm{ml}$ & 2 times \\
Vitamin C & Laroscorbine $\mathbf{5 0 0} \mathbf{~ m g}$ & France & $5 \mathrm{ml}$ & 10 times \\
Piracetam & Nootropyl $\mathbf{1 2} \mathbf{g}$ & Switzerland & $60 \mathrm{ml}$ & 3 times \\
\hline
\end{tabular}

Figure 5. First stem cell treatment from 20/12/2014 to 27/01/2015. The protocol has previewed the use of supportive medication to improve the immunity and anti-oxidative condition of the patient, the use of erythropoietin has been used to improve bone marrow activity and anemia condition, the use of extract from human placenta which has been used for the first time in such case has been used to improve regeneration process of tissue and cells of patient due to the presence several growth factors such as VEGF, HGF and TG beta.

\begin{tabular}{|c|c|c|c|c|}
\hline Vitamin K1 & Phytomenadione & Gemany & $1 \mathrm{ml}$ & 1 time \\
\hline Vitamin B & Becozyme & France & $2 \mathrm{ml}$ & 1 time \\
\hline Vitamin C & Laroscorbine $500 \mathrm{mg}$ & France & $5 \mathrm{ml}$ & 4 times \\
\hline Cholecalciferol & Vitamin D3 $200.000 \mathrm{UI} / \mathrm{ml}$ & France & $1 \mathrm{ml}$ & 3 times \\
\hline Hydrocortison $100 \mathrm{mg}$ & Hydrocortison & VietNam & $1 \mathrm{~g}$ & 3 times \\
\hline Recombinant Human Erythropoietin & Hemax 4000IU & Argentina & $1 \mathrm{ml}$ & 3 times \\
\hline Piracetam & Nootropil 12 g & Switzerland & $60 \mathrm{ml}$ & 1 time \\
\hline Human Placenta Extract & $\begin{array}{l}\text { Placenta Lucchini } \\
\text { Placenta Laennec }\end{array}$ & $\begin{array}{l}\text { Switzerland } \\
\text { Japan }\end{array}$ & $0.5 \mathrm{ml}$ & 10 times \\
\hline L-Ornithine-L-Aspartate 500 mg/5ml & Inbionethepatin & Korea & $5 \mathrm{ml}$ & 8 times \\
\hline Iron sucrose & Venofer 20 mg & Netherlands & $5 \mathrm{ml}$ & 1 time \\
\hline
\end{tabular}

Figure 6. Second treatment from 03/02/2015 to 12/02/2015. The protocol has previewed the use of supportive medication to improve the immunity and anti-oxidative condition of the patient, the use of hydrocortison has been used to reduce inflammatory process of due to the infection. 


\begin{tabular}{lllll}
\hline Vitamin K1 & Phytomenadione $\mathbf{1 0} \mathbf{~ m g}$ & Germany & $1 \mathrm{ml}$ & 1 time \\
Vitamin B & Becozyme & France & $2 \mathrm{ml}$ & 1 time \\
Cholecalciferol & Vitamin D3 200.000 UI/ml & France & $1 \mathrm{ml}$ & 13 times \\
L-Ornithine-L-Aspartate $500 \mathrm{mg} / 5 \mathrm{ml}$ & Inbionethepatin & Korea & $5 \mathrm{ml}$ & 22 times \\
Piracetam & Nootropyl 12 g & Switzerland & $60 \mathrm{ml}$ & 9 times \\
Recombinant Human Erythropoietin & Hemax 4000IU & Argentina & $1 \mathrm{ml}$ & 6 times \\
Human Placenta Extract & Placenta Lucchini & Switzerland & $0.5 \mathrm{ml}$ & 21 times \\
Human Placenta Extract & Placenta Laennec & Japan & $0.5 \mathrm{ml}$ & 3 times \\
Iron sucrose & Venofer $\mathbf{2 0} \mathbf{~ m g}$ & Netherlands & $5 \mathrm{ml}$ & 1 time \\
L-acid amin $40 \mathrm{~g}$ & Alvesin $\mathbf{4 0}$ & Netherlands & $250 \mathrm{ml}$ & 1 time \\
Glutathione & Venescy & Switzerland & $10 \mathrm{ml}$ & 5 times \\
\hline
\end{tabular}

Figure 7. Third treatment from 13/02/2015 to 26/05/2015. The protocol has previewed the use of supportive medication to improve the immunity and anti-oxidative condition of the patient, the use of iron and amino acids has been used to reduce inflammatory process of due to the infection and improve the blood quality.
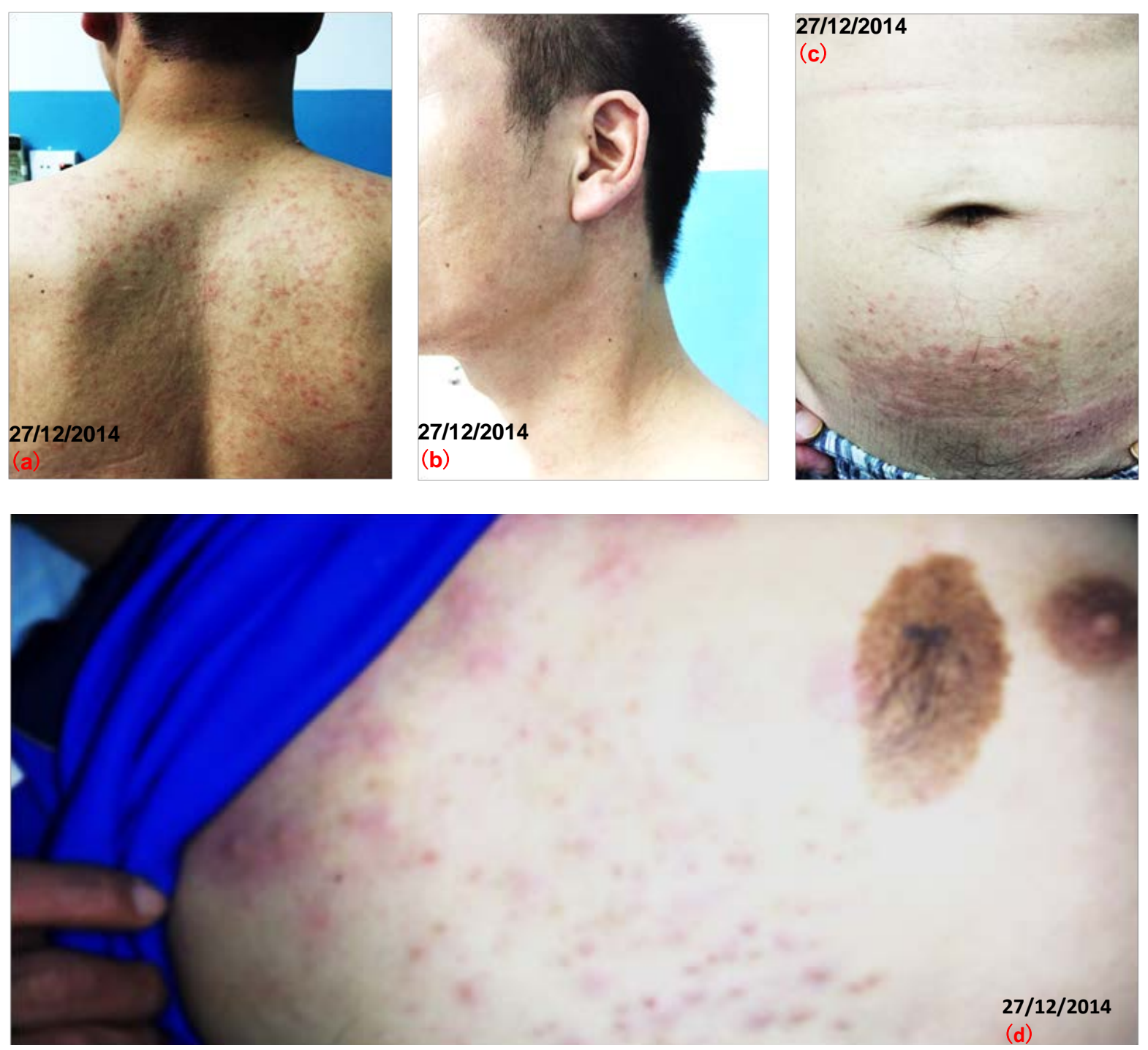

Figure 8. (a)-(d) show the patient with skin rashes and infection. Pictures have been taken in our facility soon after the HIV was confirmed. The patient presented the whole complication of an advanced HIV infection. Skin contradistingued by eruption and urticaria, diarrhea and lung infection were the main signs of a progressive deterioration. 


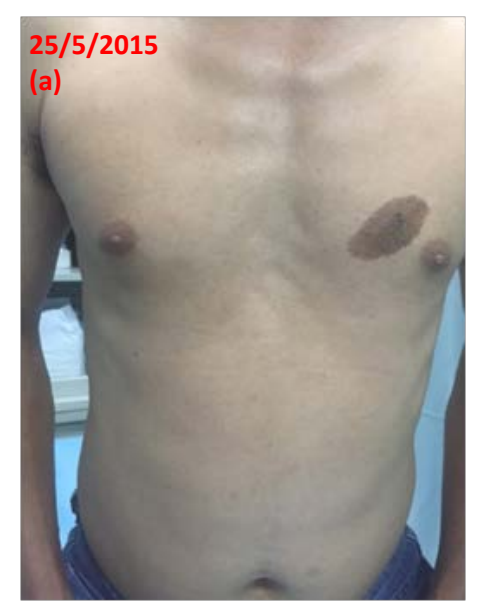

$25 / 5 / 2015$

(d)

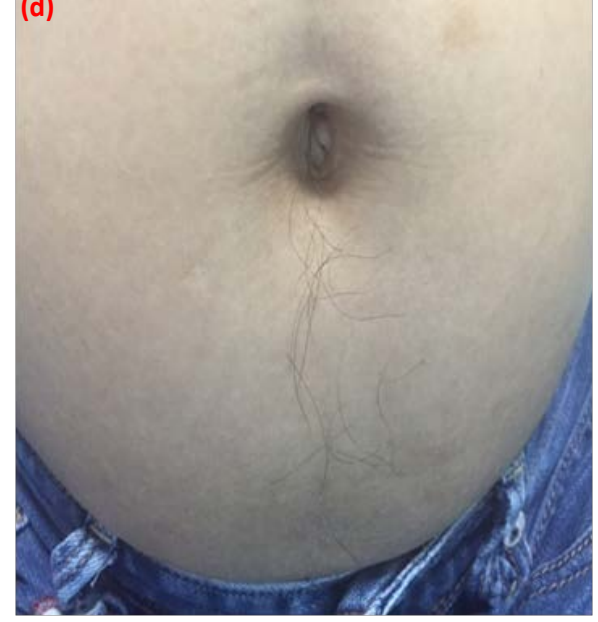

\section{$25 / 5 / 2015$}

(c)
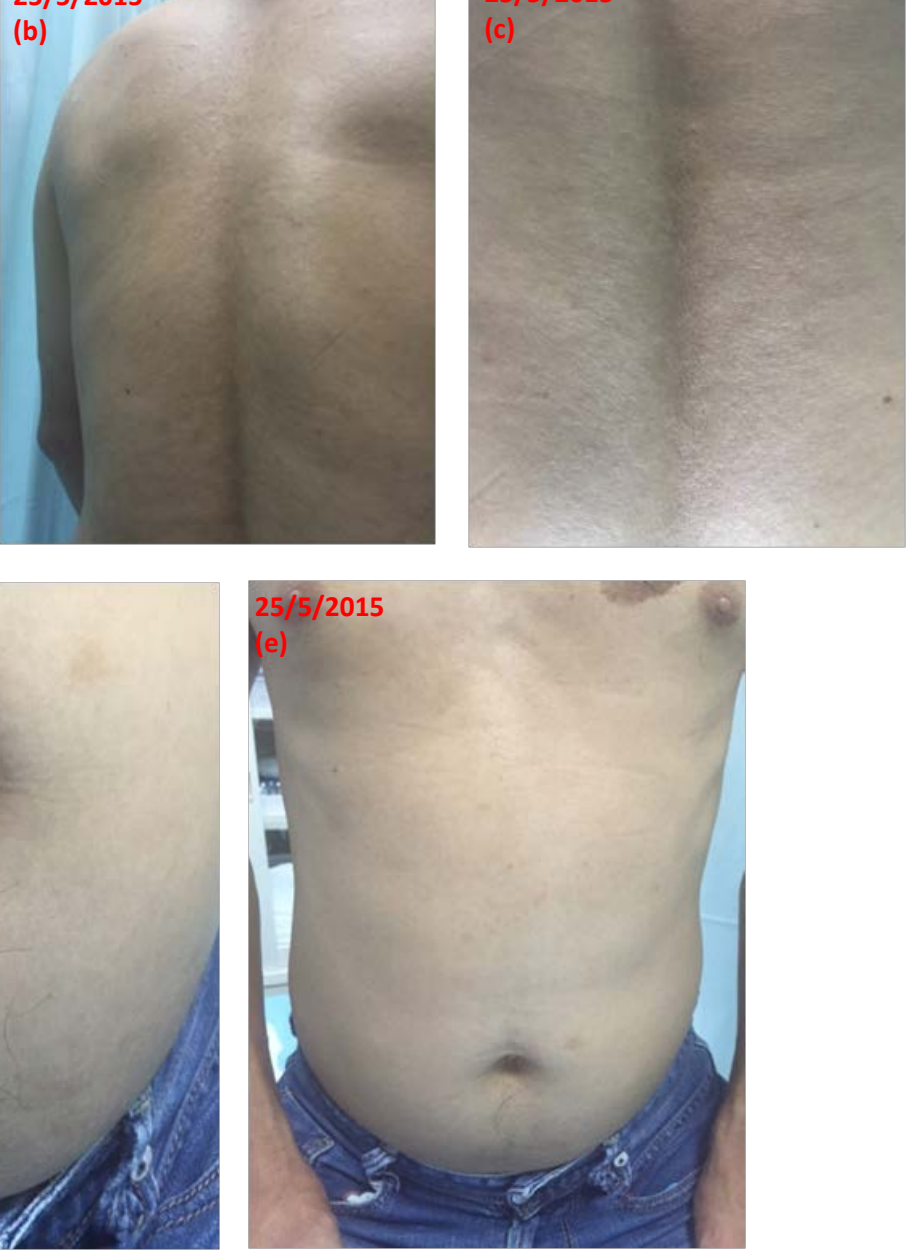

Figure 9. (a)-(e) after 5 months c.ca the patient has been invited to check and follow the clinical symptoms. By this time all skin condition was cleaned and recovered completely. The patient course recovery after the therapy was quite fast. The diarrhea and skin erythema was completely under control. The suppose mechanism bases upon the activity of regenerative and reparative mechanism of both stem cells and $\delta / \gamma \mathrm{T}$ cells.
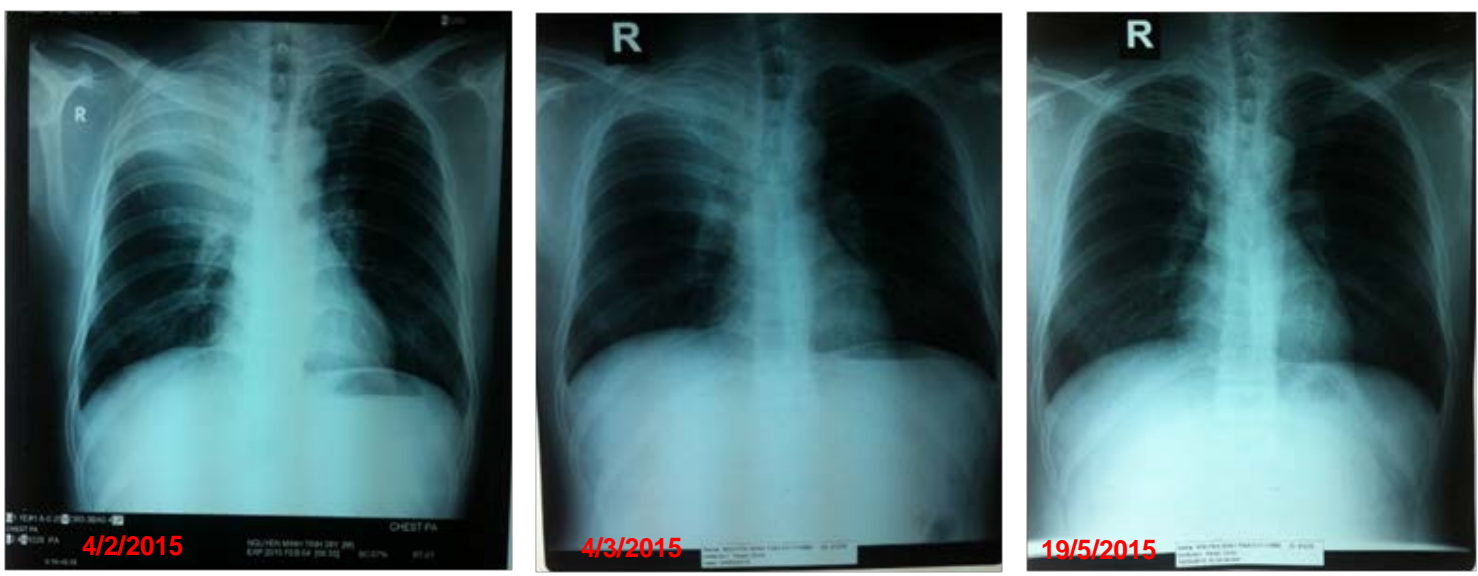

Figure 10. X ray has been performed during the stem cell and $\gamma / \delta$ T cell treatment. Bacteremia Pneumoniae is probably caused by Acinetobacter spp. Pneumonia due to opportunistic bacterial infection as secondary HIV infection could be deadly. By April 19 the patient’s chest X-ray does not show signs of pneumonia anymore. 
analysis have in a certain way confirmed this trend showing increased TCD4, increased ratio of CD4-CD8, CD19 (B lymphocytes) normal level, undetectable viral load activity and normal presence of CD16-56 (NK cells) and CD3 (protein tyrosine kinase-linked T-cell receptor/T stem cell in Thymus gland) (Figures 11-13). Of note, Beziat and colleagues have already confirmed that NK cell differentiation from hematopoietic stem cell precursors primarily gives rise to CD56 CD16 cells [37]. In specific CD56 NK cells are the first lymphocytes to be

\begin{tabular}{|c|c|c|c|c|c|}
\hline HIV CD4-CD8 & $\begin{array}{c}\text { Results } \\
(10 / 12 / 2014) \text { before }\end{array}$ & $\begin{array}{c}\text { Results } \\
(14 / 1 / 2015) \text { during }\end{array}$ & $\begin{array}{c}\text { Results } \\
(20 / 4 / 2015) \text { After }\end{array}$ & $\begin{array}{c}\text { Result } \\
(27 / 05 / 2015)\end{array}$ & Normal index \\
\hline WBC & 4.17 & 8.23 & 5.48 & & $(4.0-10.0) 10^{9} / \mathrm{L}$ \\
\hline Lym & 22.9 & 29.7 & 42.5 & & $(25 \%-45 \%)$ \\
\hline LYM\# & 0.95 & 2.44 & 2.33 & & $10^{9} / \mathrm{L}$ \\
\hline Cell ratio TCD4 & 2.6 & 8.9 & 8.8 & & $(29.5 \%-41.9 \%)$ \\
\hline Cell numbers TCD4 & 25.00 & 217.00 & 205.00 & & $\left(576-1254 \mathrm{~mm}^{3}\right)$ \\
\hline Cell ratio TCD8 & 63.7 & 76 & 70.2 & & $(20.39 \%-31.31 \%)$ \\
\hline Cell numbers TCD8 & 605.00 & 1854.00 & 1636.00 & & $\left(381-871 \mathrm{~mm}^{3}\right)$ \\
\hline Ratio TCD4/TCD8 & 0.04 & 0.12 & 0.13 & 0.2 & $(1.07 \%-1.99 \%)$ \\
\hline Anti HIV & POS & POS & POS & & Negative \\
\hline RT-PCR Virus Loading & POS & NEG & & NEG (28/5/2015) & Negative \\
\hline
\end{tabular}

Figure 11. Lymphocyte CD4-CD8 count performed during different time within a period of 5 months c.ca. HIV CD4-CD8 count performed during different time within a period of 5 months c.ca. Results show a steady and progressive amelioration of patient's immunity.

CD3/CD16+56/CD45/CD4/CD19/CD8 TruC
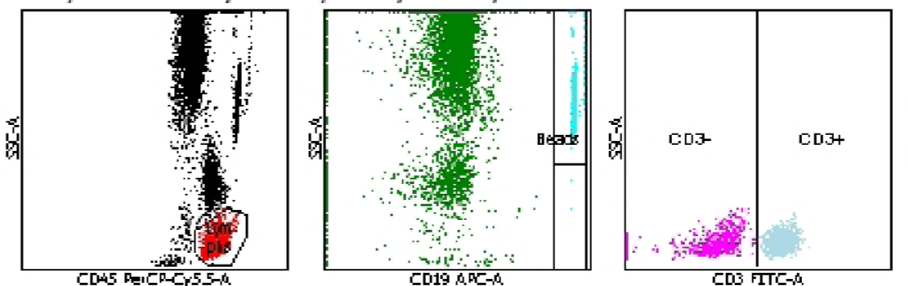

CDS FIT-

L-001003.001.fos

\begin{tabular}{|l|r|r|}
\hline Parameter & Percent & Value/AbsCnt \\
\hline Lymph Events & & 2502 \\
\hline Bead Events & & 1649 \\
\hline CD3+ & 72.38 & 1195.99 \\
\hline CD3+CD8+ & 58.59 & 968.15 \\
\hline CD3+CD4+ & 11.47 & 189.53 \\
\hline CD3+CD4+CD8+ & 0.08 & 1.32 \\
\hline CD16+CD56+ & 6.95 & 114.91 \\
\hline CD19+ & 20.18 & 333.50 \\
\hline CD45+ & & 1652.32 \\
\hline $4 / 8$ Ratio & & 0.20 \\
\hline
\end{tabular}

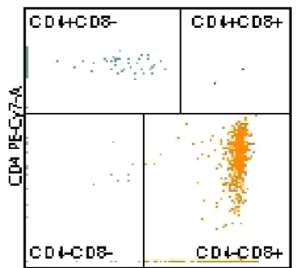

CDA $A D C-r^{7-4}$
Total Events: 12845

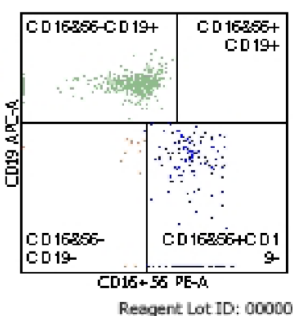

\section{QC Messages}

$\%$ T-Sum is: 2.32

Lymphosum is: 99.52

4/8 ratio is: 0.20

Figure 12. Data showed that the immune system T, B lymphocytes are increasing slowly but steady and NK cells are rising. Of note the normal range presence of CD3, 16-56 NK precursor cells show that the immune system has had the capacity of blocking secondary bacterial infection and is inhibiting viral and infection progression. Normal range 2114 cells/ $\mu \mathrm{L}$ for total lymphocytes, CD3 $0.69-2.54 \times 10^{3}$ (55-84 normal), CD3+CD8+ 10.50\% - 44.30\% (normal/high), CD3+CD4+ 29.00\% $67.10 \%-0.41-1.59 \times 10^{3}$ (low), CD3+CD4+CD8+ 31\% - 41\% (low), CD16+CD56+ 1.90\% - 19.60\% (normal), CD19+ 8\% $-20 \%$ (normal), CD45+ 4.000-10.000 leukocytes/ $\mu \mathrm{L}$ for adult subjects, CD4:CD8 ratio (0.4 - 2.89). 


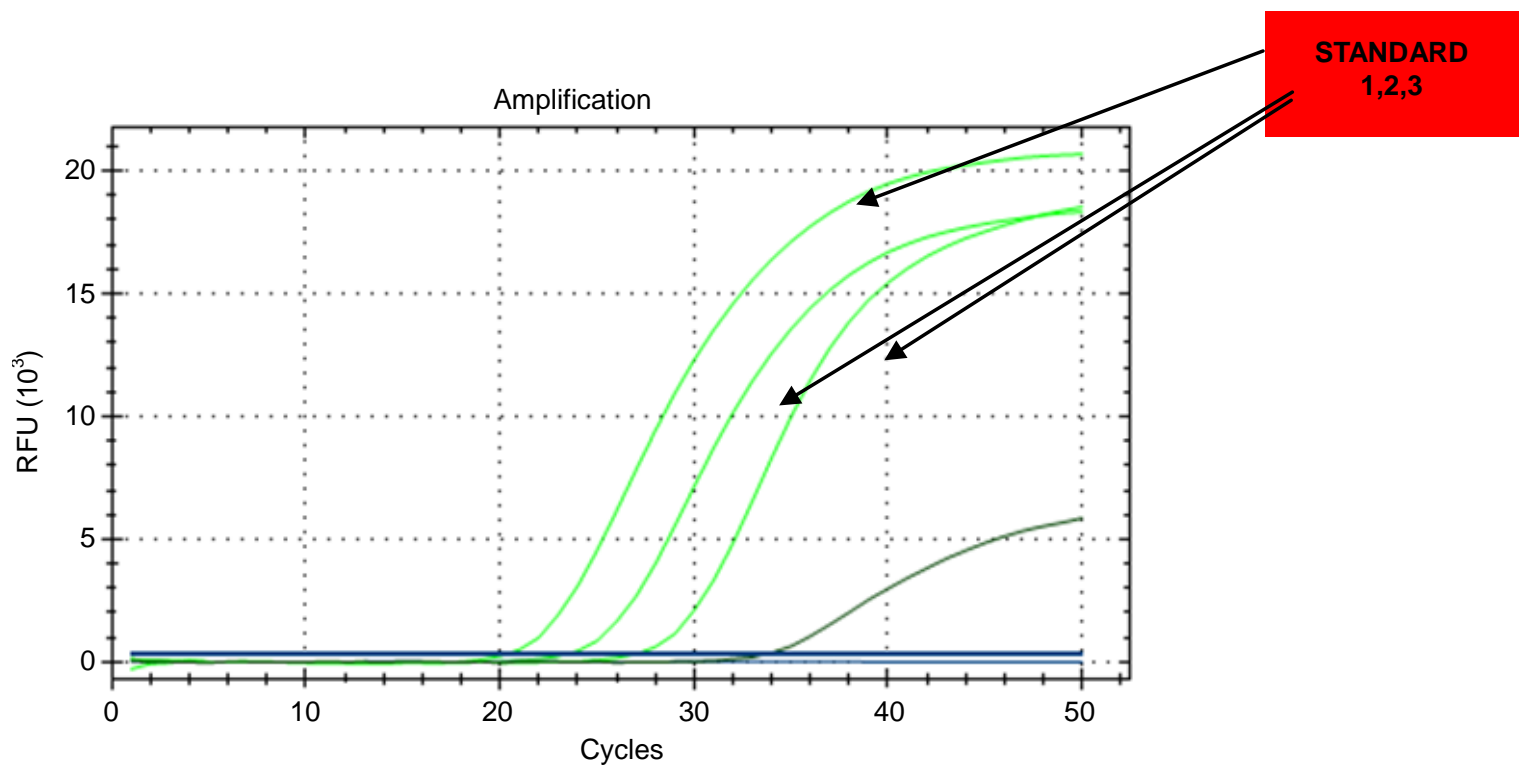

Figure 13. RT-PCR on HIV viral load. The test was performed 3 times. RT-PCR on HIV viral load confirmed that the virus activity was under the treshold level, or 100 copies/ml. HIV-RNA PCR the virus load was under the detected threshold the lower limit of 100 copies/ml both in 15/01/2915 and 27/05/2015.

generated following hematopoietic stem cell transplantations [37]. Though, CD3-CD56 NKT-like cells activity has been reported in the activation and regulation within multiple stages of immune system, data on their role in HIV infection are rare [38]. In a comparative study it was proved that expression of IFN- $\gamma$ by PMA/ionomycinactivation in CD3 + CD56 + NKT-like cells was definitively more significant in HIV-non-infected subjects than in controls. Though the mechanism is still not clear, this would suggest that CD3 + CD56 + NKT-like cells might play a sort of preventing and control role in HIV-1infection transmission [39]. Therefore, we assume that hPB-SCs and $\delta / \gamma$ T cells may have important functional activity that enhances the recovery of immune system response on multiple level which secures the progress of HIV infection. These modifications may function as a protective shield which limits viral further contamination by lowering down HIV progression.

\section{Conclusion}

To conclude, we are seriously aware of the non-conclusive results of this case report, as scientists yet have to unveil all the effectiveness and potentials of hPB-SCs as well as $\delta / \gamma \mathrm{T}$ cells in the field of bacteria, fungal and viral infectious disorders. Additional efforts should be done to better clarify the direct and indirect relation existing between PB-Stem SCs and $\delta / \gamma$ T cells and, more verifications are definitively needed to confirm their ultimate influence on the different branches of immune system and thus elucidate their inhibitory mechanism on HIV progression and transmission. In addition, retrospective study from established databases remains incomplete, especially in those patients "lost to follow-up" which are presumed to be still alive and/or under retro-viral medication. We should also admit that there is a lack of homogenous and uniform procedure together with a common agreement on cell product to be used due to the fact that many expansion media are enriched with growth factors and bovine sera that may affect negatively on major histocompatibility complex class II expression and karyotype stability [40] [41]. Nevertheless, the introduction of new stem cells procedures and protocols has reduced the need for more radical therapies though in a future prospective, randomized clinical trials will be essential in deciding the outcome of this therapy.

\section{References}

[1] Mootsikapun, P. (2007) Bacteremia in Adult Patients with Acquired Immunodeficiency Syndrome in the Northeast of Thailand. International Journal of Infectious Disease, 11, 226-231. http://dx.doi.org/10.1016/j.ijid.2006.02.010

[2] Krumholz, H.M., Sande, M.A. and Lo, B. (1989) Community-Acquired Bacteremia in Patients with Acquired Immunodeficiency Syndrome: Clinical Presentation, Bacteriology, and Outcome. American Journal of Medicine, 86, 776- 
779. http://dx.doi.org/10.1016/0002-9343(89)90472-5

[3] Manfredi, R., Cosiglioga, P., Ricchi, E. and Chiodo, F. (1993) Sepsis-Bacteremia and Other Infections Due to NonOpportunistic Bacterial Pathogens in a Consecutive Series of 788 Patients Hospitalized for HIV Infection. Clinical Therapeutics, 143, 279-290.

[4] Tumbarello, M., Tacconelli, E., Caponera, S., Cauda, R. and Ortona, L. (1995) The Impact of Bacteremia on HIV Infection. Nine Years Experience in a Large Italian University Hospital. Journal of Infection, 31, 123-131. http://dx.doi.org/10.1016/S0163-4453(95)92110-9

[5] Kovacs, A., Leaf, H.L. and Simberkoff, M.S. (1997) Bacterial Infections. Medical Clinics of North America, 81, 319343. http://dx.doi.org/10.1016/S0025-7125(05)70520-4

[6] Huang, L. and Crothers, K.A. (2010) HIV-Associated Pneumonias. NIH, 1-19.

[7] Fichtenbaum, C.J., Dunagan, W.C. and Powderly, W.G. (1995) Bacteremia in Hospitalized Patients Infected with HIV: A Case Control Study of Risk Factors and Outcome. Journal of Acquired Immune Deficiency Syndrome, 8, 51-57.

[8] Tumbarello, M., Tacconelli, E., de Gaetano Donati, K., Leone, F., Morace, G., Cauda, R. and Ortona, L. (1998) Nosocomial Bloodstream Infections in HIV-Infected Patient: Attributable Mortality and Excess Hospital Stay. Journal of Acquired Immune Deficiency Syndrome \& Human Retrovirology, 19, 490-496. http://dx.doi.org/10.1097/00042560-199812150-00008

[9] Afessa, B., Morales, I. and Weaver, B. (2001) Bacteremia in Hospitalized Patient with Human Immunedeficiency Virus: A Prospective Cohort Study. BMC Infectious Diseases, 1, 1-13. http://dx.doi.org/10.1186/1471-2334-1-13

[10] Whimbey, E., Gold, J.W., Polsky, B., Dryjanski, J., Hawkins, C., Blevins, A., Brannon, P., Kiehn, T.E., Brown, A.E. and Armstrong, D. (1986) Bacteremia and Fungemia in Patients with the Acquired Immunodeficiency Syndrome. Annals of Internal Medicine, 104, 511-514. http://dx.doi.org/10.7326/0003-4819-104-4-511

[11] Bouza, E. and Rodriguez-Creixems, M. (1999) Bacteremic Infection in the HIV Infected Patients and Recurrent Bacteremia. Clinical Microbiology and Infections, 5, 2s33-2s39.

[12] Ashkenazi, S., Leibovici, L., Samra, Z., Konisberger, H. and Drucker, M. (1992) Risk Factors for Mortality Due to Bacteremia and Fungemia in Childhood. Clinical Infectious Disease, 14, 949-951. http://dx.doi.org/10.1093/clinids/14.4.949

[13] Manfredi, R., Cosiglioga, P., Ricchi, E. and Chiodo, F. (2001) Pathogenic Role of Acinetobacter Spp during HIV Infection. Infezione Medicale, 9, 43-51.

[14] Manfredi, R., Cosiglioga, P., Ricchi, E. and Chiodo, F. (2001) Acinetobacter Infections in Patients with Human Immunodeficiency Virus Infection: Microbiological and Clinical Epidemiology. Chemotherapy, 47, 19-28. http://dx.doi.org/10.1159/000048497

[15] (2014) Vietnam AIDS Response Report 2014: Following up the 2011 Political Declaration on HIV AIDS. 1-118.

[16] Beyer, C. (2007) HIV Epidemiology Update and Transmission Factors: Risks and Risk Contexts-16th International AIDS Conference Epidemiology Plenary. Clinical Infectious Disease, 44, 981-987. http://dx.doi.org/10.1086/512371

[17] Aceijas, C., Stimson, G.V., Hickman, M. and Rhodes, T. (2004) Global Overview of Injecting Drug Use and HIV Infection among Injecting Drug Users. AIDS, 18, 2295-2303. http://dx.doi.org/10.1097/00002030-200411190-00010

[18] Zamani, S., Kihara, M., Gouya, M.M., Vazirian, M., Nassirimanesh, B., Ono-Kihara, M., et al. (2006) High Prevalence of HIV Infection Associated with Incarceration among Community-Based Injecting Drug Users in Tehran, Iran. Journal of Acquired Immune Deficiency Syndrome, 42, 342-346. http://dx.doi.org/10.1097/01.qai.0000219785.81163.67

[19] United Nations' Office on Drugs and Crime (UNODC) (2006) World Drug Report for 2005. United Nations Publications, New York.

[20] Gargiulo, C., Pham, V.H., Nguyen, T.H., Nguyen, C.D.K., Phuc, P.V., Abe, K., Flores, V. and Shiffman, M. (2015) Isolation and Characterization of Multipotent and Pluripotent Stem Cells from Human Peripheral Blood. Journal of Stem Cells Development, 5, 1-16. http://dx.doi.org/10.4236/scd.2015.53003

[21] Thierry, G., Rubinstein, D.B. and Symann, M. (1992) Immune Reconstitution and Immunotherapy after Autologous Hematopoietic Stem Cell Transplantation. Blood, 92, 1471-1490.

[22] Philip, T., Guglielmi, C., Hagenbeek, A., Somers, R., Van Der Lelie, H., Bron, D., Sonneveld, P., Gisselbrecht, C., Cahn, J.-Y., Harousseau, J.-L., Coiffier, B., Biron, P., Mandelli, F. and Chauvin, F. (1995) Autologous Bone Marrow Transplantation as Compared with Salvage Chemotherapy in Relapses of Chemotherapy-Sensitive Non-Hodgkin's Lymphoma. New England Journal of Medicine, 333, 1540-1545. http://dx.doi.org/10.1056/NEJM199512073332305

[23] Zittoun, R.A., Mandelli, F., Willemze, R., De Witte, T., Labar, B., Resegotti, L., Leoni, F., Damasio, E., Visani, G., Papa, G., Caronia, F., Hayat, M., Stryckmans, P., Rotoli, B., Leoni, P., Peetermans, M.E., Dardenne, M., Vegna, M.L., Petti, M.C., Solbu, G. and Suciu, S. (1995) Autologous or Allogeneic Bone Marrow Transplantation Compared with Intensive Chemotherapy in Acute Myelogenous Leukemia. New England Journal of Medicine, 332, 217-223. http://dx.doi.org/10.1056/NEJM199501263320403 
[24] Attal, M., Harousseau, J.L., Stoppa, A.M., Sotto, J.J., Fuzibet, J.G., Rossi, J.F., Casassus, P., Maisonneuve, H., Facon, T., Ifrah, N., Payen, C. and Bataille, R. (1996) A Prospective, Randomized Trial of Autologous Bone Marrow Transplantation and Chemotherapy in Multiple Myeloma. New England Journal of Medicine, 335, 91-97. http://dx.doi.org/10.1056/NEJM199607113350204

[25] Humblet, Y., Symann, M., Bosly, A., Delaunois, L., Francis, C., Machiels, J., Beauduin, M., Doyen, C., Weynants, P., Longueville, J. and Prignot, J. (1987) Late Intensification Chemotherapy with Autologous Bone Marrow Transplantation in Selected Small Cell Carcinoma of the Lung: A Randomized Study. Journal of Clinical Oncology, 5, 1864-1873.

[26] Bezwoda, W.R., Seymour, L. and Dansey, R.D. (1995) High-Dose Chemotherapy with Hematopoietic Rescue as Primary Treatment for Metastatic Breast Cancer: A Randomized Trial. Journal of Clinical Oncology, 13, $2483-2489$.

[27] Damiani, D., Stocchi, R., Masolini, P., Michelutti, A., Sperotto, A., Geromin, A., Skert, C., Cerno, M., Michieli, M., Baccarani, M. and Fanin, R. (2001) Dendric Cells Recover after Autologous Stem Cell Transplantation. Bone Marrow Transplantation, 30, 261-266. http://dx.doi.org/10.1038/sj.bmt.1703637

[28] Di Nicola, M. and Lemoli, R.M. (2000) Dendritic Cells: Specialized Antigen Presenting Cells. Haematologica, 85, 202-207.

[29] Bachereau, T. and Steinman, R.M. (1998) Dendritic Cells and the Control of Immunity. Nature, 392, 245-252. http://dx.doi.org/10.1038/32588

[30] Patel, A.N. and Genovese, J. (2011) Potential Clinical Applications of Adult Human Mesenchymal Stem Cell (Prochymal $\left.{ }^{\circledR}\right)$ Therapy. Stem Cells and Cloning: Advances and Applications, 4, 61-72.

[31] Matsubara, H., Makimoto, A., Takayama, J., Higa, T., Saito, T., Kanda, Y., Tanosaki, R., Mineishi, S., Ohira, M. and Takaue, Y. (2001) Possible Clinical Benefits of the Use of Peripheral Blood Stem Cells Over Bone Marrow in the Allogeneic Transplantation Setting for the Treatment of Childhood Leukemia. Japanese Journal of Clinical Oncology, 31, 30-34. http://dx.doi.org/10.1093/jico/hye001

[32] Girardi, M. (2006) Immune Surveillance and Immune Regulation by $\gamma / \delta$ T Cells. Journal of Investigative Dermatology, 126, 25-31. http://dx.doi.org/10.1038/sj.jid.5700003

[33] Chen, Z.W. and Letvin, N.L. (2003) $\mathrm{V} \gamma 2 \mathrm{~V} \delta 2^{+} \mathrm{T}$ Cells and Anti-Microbial Immune Responses. Microbes and Infection, 5, 491-498. http://dx.doi.org/10.1016/S1286-4579(03)00074-1

[34] Kabelitz, D., Marischen, L., Oberg, H.H., Holtmeier, W. and Wesch, D. (2005) Epithelial Defense by $\gamma \delta$ T Cells. International Archive of Allergy and Immunology, 137, 73-81. http://dx.doi.org/10.1159/000085107

[35] Smith, A.L. and Hayday, A.C. (2000) An $\alpha \beta$ T-Cell-Independent Immunoprotective Response towards Gut Coccidia Is Supported by $\gamma \delta$ Cells. Immunology, 101, 325-332. http://dx.doi.org/10.1046/j.1365-2567.2000.00122.x

[36] Brandes, M., Willimann, K. and Moser, B. (2005) Professional Antigen-Presentation Function by Human $\gamma \delta$ T Cells. Science, 309, 264-268. http://dx.doi.org/10.1126/science.1110267

[37] Béziat, V., Duffy, D., Nguyen Quoc, S., Le Garff-Tavernier, M., Decocq, J., Combadière, B., Debré, P. and Vieillard, V. (2011) CD56 ${ }^{\text {Bright }}$ CD $16^{+}$NK Cells: A Functional Intermediate Stage of NK Cell Differentiation. Journal of Immunology, 186, 6753-6761. http://dx.doi.org/10.4049/jimmunol.1100330

[38] Jiang, Y.J., Cui, X.J., Cui, C., Zhang, J., Zhou, F.Y., Zhang, Z.N., Fu, Y.J., Xu, J.J., Chu, Z.X., Liu, J., Han, X.X., Liao, C., Wang, Y., Cao, Y.M. and Shang, H. (2014) The Function of CD3 ${ }^{+}$, CD56 ${ }^{+}$NKT-Like Cells in HIV-Infected Individuals. BioMedResearch International, 2014, Article ID: 863625.

[39] Montoya, C.J., Velilla, P.A., Chougnet, C., Landay, A.L. and Rugeles, M.T. (2006) Increased IFN- $\gamma$ Production by NK and CD3+/CD56+ Cells in Sexually HIV-1-Exposed but Uninfected Individuals. Clinical Immunology, 120, 138-146. http://dx.doi.org/10.1016/j.clim.2006.02.008

[40] Bocelli-Tyndall, C., Zajac, P. and Di Maggio, N. (2010) Fibroblast Growth Factor 2 and Platelet-Derived Growth Factor, but Not Platelet Lysate, Induce Proliferation-Dependent, Functional Class II Major Histocompatibility Complex Antigen in Human Mesenchymal Stem Cells. Arthritis and Rheumatology, 62, 3815-3825. http://dx.doi.org/10.1002/art.27736

[41] Tarte, K., Gaillard, J. and Lataillade, J.J. (2010) Clinical-Grade Production of Human Mesenchymal Stromal Cells: Occurrence of Aneuploidy without Transformation. Blood, 115, 1549-1553. http://dx.doi.org/10.1182/blood-2009-05-219907 